\title{
Correction to: Improved allometric proxies for eelgrass conservation
}

\author{
A. Montesinos-López ${ }^{1} \cdot$ E. Villa-Diharce ${ }^{2} \cdot$ H. Echavarría-Heras ${ }^{3} \cdot$ C. Leal-Ramírez ${ }^{3}$
}

Published online: 23 August 2018

(C) The Author(s) 2018

\section{Correction to: Journal of Coastal Conservation https://doi.org/10.1007/s11852-018-0639-4}

The article Improved allometric proxies for eelgrass conservation, written by A. Montesinos-López, E. Villa-Diharce, H. Echavarría-Heras, and C. Leal-Ramírez, was originally published electronically on the publisher's internet portal (currently SpringerLink) on July 30, 2018 without open access. With the author (s)' decision to opt for Open Choice, the copyright of the article changed on August 2018 to $($ C) The Author (s) 2018 and the article is forthwith distributed under the terms of the Creative Commons Attribution 4.0 International License (http://creativecommons.org/licenses/by/4.0/), which permits use, duplication, adaptation, distribution and reproduction in any medium or format, as long as you give appropriate credit to the original author (s) and the source, provide a link to the Creative Commons license and indicate if changes were made.

The original article has been corrected.

Open Access This article is distributed under the terms of the Creative Commons Attribution 4.0 International License (http:// creativecommons.org/licenses/by/4.0/), which permits unrestricted use, distribution, and reproduction in any medium, provided you give appropriate credit to the original author(s) and the source, provide a link to the Creative Commons license, and indicate if changes were made.

The online version of the original article can be found at https://doi.org/ $10.1007 /$ s11852-018-0639-4

H. Echavarría-Heras

heheras@icloud.com

A. Montesinos-López

aml@ cimat.mx

E. Villa-Diharce

villadi@cimat.mx

C. Leal-Ramírez

cleal@cicese.mx

1 Departamento de Matemáticas, Centro Universitario de Ciencias Exactas e Ingenierías (CUCEI), Universidad de Guadalajara, 44430 Guadalajara, Jalisco, Mexico

2 Centro de Investigación en Matemáticas, Callejón Jalisco, s/n, Valenciana, 36023 Guanajuato, Mexico

3 Centro de Investigación Cientifica y de Estudios, Superiores de Ensenada, Carretera Tijuana-Ensenada 3918, Fraccionamiento Zona Playitas, 22860 Ensenada, B.C., Mexico 